This item was submitted to Loughborough's Research Repository by the author.

Items in Figshare are protected by copyright, with all rights reserved, unless otherwise indicated.

\title{
Private sector involvement
}

PLEASE CITE THE PUBLISHED VERSION

PUBLISHER

(c) WEDC, Loughborough University

VERSION

VoR (Version of Record)

\section{PUBLISHER STATEMENT}

This work is made available according to the conditions of the Creative Commons Attribution-NonCommercialNoDerivatives 4.0 International (CC BY-NC-ND 4.0) licence. Full details of this licence are available at: https://creativecommons.org/licenses/by-nc-nd/4.0/

\section{LICENCE}

CC BY-NC-ND 4.0

\section{REPOSITORY RECORD}

Baumann, Erich. 2019. “Private Sector Involvement”. figshare. https://hdl.handle.net/2134/29402. 


\title{
WATER, SANITATION, ENVIRONMENT and DEVELOPMENT Private sector Involvement
}

\author{
Erich Baumann
}

\section{Introduction}

To establish the construction, drilling, manufacture and maintenance capability in the country it is necessary to follow a clearly defined policy framework under which a transition from the present "construction by GWSC projects" to a future "construction by private sector" is realized. Standardization and clearly defined regulations are the essential precondition to make this step. The private sector can only successfully operate if GWSC, ESAs and NGOs coordinate their activities and policies in such a way that all private enterprises have a chance to obtain work in a free competitive environment. Procurement practices have to change from International Competitive Bidding to Local Competitive Bidding. A key factor for the development of a strong private sector is the coordination of sector activities at regional and district level.

\section{Technical specifications}

Standardization and clearly defined regulations are essential preconditions to change the sector. Provision of goods and services through the private sector has to be achieved through a clearly defined technical regulatory system. GWSC will have to standardize the technologies used. Standard designs would be established for (1) Latrines, (2) Hand dug wells with cement block lining and with insitu lining, well head design for handpump, (3) Boreholes, 4", 5" and 6" in diameter, well pad design, (4) Handpumps, direct action, deep well, (5) Small piped systems, solar-, solar/ hybrid-, diesel/electric, electric pumps, storage tanks, piping, standpipes. For each technology complete technical specification, including drawings, bills of quantities, production procedures and quality control requirements, will have to be worked out. Similarly, rules and guidelines for operation and maintenance will be formulated. These technical specifications would be the basis for any local or international competitive bidding.

The decision to standardize on equipment has been endorsed by the GOG (PNDC Committee of Secretaries). GWSC will have to build the capacity in a Technical Department with the necessary personnel to maintain and administer the standards and specifications.

The private sector participation in the formulation of standards would be achieved by inviting associations of drilling companies, handpump suppliers and/or construction companies to take part in the elaboration and the review of the standards. These associations would have seats allocated in the standards review committees.

\section{Pre-qualification of suppliers}

The next step will be the identification of suppliers and/or manufacturers that are capable of producing the products/ services as specified. Information will be gathered on: a) Technical ability; b) Infrastructure/equipment availability and type; c) Financial capability; d) Past performance; e) Internal quality control. If the above criteria are satisfied a works inspection will be carried out by a inspection agency to verify the data received. A trial order will be placed with the prospective supplier. During the execution of the trial order visits to site/factory will be made to ascertain whether the necessary technical, managerial skills are available and the quality control system is in place. These visits will reveal where the contractor is deficient and what specific training may be required. A supplier/contractor that has passed the above procedure may be registered as a Certified Supplier. Only suppliers that have reached this status will be eligible for participation in bidding on subsidized contracts. The performance of the contractor will be reviewed on an annual basis. Defaulters will lose their license to operate. Depending on the nature of the work, pre-qualification may be done on national level (drilling contractors, handpump suppliers, etc.), on regional level (hand dug well and latrine contractors, maintenance contractors, community animation contractors).

\section{Manufacture and distribution of handpumps}

It can be estimated that the market in Ghana will eventually be 2,500 to 3,000 pumps per year. The local manufacturers could cover approx. 50 to $60 \%$ of this market, i.e. about 1,200 to 1,800 pumps per annum.

The investments required for equipment and tooling as well as the high working capital demand constrain the choice of companies. Small scale and cottage industries would financially not be able to undertake such a venture and would not have the managerial ability for sustained successful production. Economic conditions in Ghana have considerably improved over the last 4-5 years. Under the Ghana Investment Code it is possible to obtain quite favourable relaxations on import restrictions and tax and duty exemptions. However it is still an uphill battle for local industries trying to survive and to compete against imported products. Handpumps can be imported duty free, and (for instance) manufacturers in India profit from export subsidies. 
Realistically, local manufacture is not always feasible. Ghana, even though theoretically large enough to sustain about 2 - 3 local manufacturers, will probably in the near future have to satisfy herself with one manufacturer for direct action pumps. In the meantime it is essential to strive towards a more comprehensive understanding of supply of handpumps for CWS/S Projects. If the pumps are supplied through the local, private sector as turn-key installations (including: supply, distribution, delivery to site, installation, training of village mechanic, provision of after-sales services) the locally added value is quite considerable.

\section{Recommended actions to improve manufacturing/distribution capacity}

Supplier (importers) and even more so local manufacturers however have to import/produce pumps in reasonable quantities. Raw material cost is about $50.60 \%$ of the sales price requiring high working capital. The establishment of after-sales services as part of the process of pre-qualification requires additional substantial capital inputs. GWSC would order an anticipated two years demand of standardized pumps. It would call for LCB for collective orders with pre-qualified suppliers. GWSC would pay an advance of $70 \%$. The produced/imported pumps would be inspected in the premises of the manufacturer/supplier by an independent inspection company and sealed. During the process of project execution the regions/projects would release the delivery of small quantities for installation. After completion of installation the supplier will be paid 20 $\%$ of the price by the community. GWSC will retain 10\% over the guarantee period of 12 months.

\section{Distribution and installation of handpumps}

Contracts for the supply of handpumps will include the provision of hardware as well as related services. The suppliers will be required to establish a comprehensive network of Regional Dealers and Spare Part outlets. These regional dealers and their area mechanics will be the backbone of the repair services. The table below indicates the division of functions for distribution and installation of handpumps:

\section{GWSC}

- Selects 2 - 3 Pump Types for Standardization

- Defines Specification

- Pre-qualifies Suppliers

\section{CWSIS project (Bilaterall and NGOs)}

- Plans the project

- Purchases Pumps

- Organizes Quality Control
- Service Contract with Supplier

- Supervises the works

\section{Supplier/manufacture}

- Imports/manufactures the pumps

- Custom clearance

- Stocks Pumps and Spares

- Appoints Regional Dealers

- Distributes Pumps to Regional Dealers

- Training of Mechanics, Area Mechanics, Installation Crews

- Marketing of the Pumps

- Liaison with Manufacturer

- After-Sales Services

\section{Regional dealer}

- Distributes Pumps to Site

- Pump Installation

- Training of Village Mechanics

- Stocks and Sells Spare Parts

- Provides Repair Services

- Liaison with Area Mechanics

\section{Area mechanic}

- Makes the annual Inspection

- Repairs Pumps and sells Spare Parts on commission

- Assists Regional Dealer in Installations

- Liaison with Community

Watsan pump mechanic

- Management of O8M

- Minor Repairs

- Collection of Inspection fee

The criteria for pre-qualification compels the suppliers to gear up to these requirements. The cost of the services provided by the private sector will affect in the cost of the handpumps. The installed price of a handpump would be approx. 1.6 to 2 times the FOB price.

Maintenance and Repair Services Community management of O\&M will not relieve the government of its continued involvement in rural water supply. It might however be possible for the government to assign some of the duties to the communities and the private sector.

GWSC will have to formulate a general maintenance strategy, for newly developed facilities as well as for existing facilities. The strategy needs be drafted in such a way that it would cater in a practical manner for the 
transition of the present O\&M system to the new CWS system, preserving the already existing infrastructures, keeping the present O\&M structures operational and thereby making best use of the personnel resources in GWSC. This strategy would be based on the following:

- Acceptance that O\&M needs to be subsidized also under community management. The strategy will include the establishment of a Rehabilitation Fund that covers certain aspects of O\&M (well maintenance, major repairs, etc.). Initially donors would inject seed money to get the fund started. The GOG would gradually take over the financial responsibility to replenish the Rehabilitation Fund by using either its own funds or counterpart funds generated with sector funding by ESAs.

- Assessment of the existing resources. GWSC Maintenance Units are not dissolved but gradually changed and incorporated into the new CWS system. Eventually privatization of the services provided by these units will be encouraged.

- Standardization of Handpumps. Involvement of the private sector for O\&M and the provision of spare parts make it mandatory to keep the number of pumps to a minimum.

- Establishment of a continued annual preventive maintenance and inspection service. Communities, when they assent to obtain a water facility, sign an agreement that they will have the facilities inspected by a GWSC approved private mechanic on a regular basis. During the inspection the fast wearing parts are exchanged. The communities will have to pay a fixed rate for this service to the mechanic. This will safeguard that the investments made by GOG are used and maintained properly.

- O\&M Support by the District Assembly would be permanently provided by the O\&M Technician of the District Water and Sanitation Team (DWST). He is responsible for advising and motivating the communities. He is the link to private mechanics. He will be responsible for maintaining the district data base of all water facilities. The O\&M Technician would be part of the team that scrutinizes the applications to the rehabilitation fund.

- Any other repairs and additional spare parts which become necessary between the inspections will have to be paid by the communities.

- Back-up for major repairs that are well outside the technical and financial capability of the communities would need to be ensured by GWSC. Borehole redevelopment would have to be organized. Presently GWSC Maintenance Unit (MU) has the capacity to maintain all the boreholes in the country. However it will be necessary to streamline and eventually privatize the $\mathrm{MU}$ operations.

In case of a major repair or borehole redevelopment the community will have the possibility to apply for financial assistance to the district assembly. Precondition to be eligible for any assistance from the rehabilitation fund would be that the community had all the annual inspections carried out. The cost sharing arrangement will include that the communities will have to pay a reasonable percentage of the cost.

- Introduction of the CWS system in some selected districts only. GWSC will carry on with the present centralized handpump maintenance system under the Maintenance Unit in the other regions for some time before changing also over to the CWS system with regular inspections. Tariff payment would stop and the $\mathrm{MU}$ would charge the communities the recommended price for the inspections. The communities in these regions would be told that a change in the maintenance system is imminent and they would be educated towards this goal. Since they have been used to paying regular tariffs it should be quite easy to motivate them to cooperate with the new maintenance structure. This approach would allow GWSC to implement a nationwide maintenance strategy in steps without compromising on the present pumps.

- Identification of what services can be privatized. Franchising of some of the services to NGOs or private companies which are acting on behalf of GWSC will be considered.

- Assistance to the private sector to develop a network that can provide the spare parts and services. Prequalification of suppliers demands that after-sales services are established in the regions and districts during the supply of the initial pumps/equipment. This will guarantee that communities have spare parts and trained mechanics in the vicinity.

Training of community pump mechanics, area mechanics and O\&M Technicians will be done by the suppliers under supervision of GWSC. District and GWSC personnel will need to be trained on all technologies.

\section{Private sector involvement in O\&M}

Suppliers of handpumps would be compelled to set up their own after-sales service network. Thus the private sector would be responsible for the supply and distribution of spare parts. Spare part distribution on its own is not economically viable. It has to be tied in with the supply of new equipment. If the renewal of pre-qualification depends on the continued availability of spares in the districts at reasonable cost, suppliers will ensure the supply of spare parts. Regional sales centres equipped with the necessary tools and spares will be set up.

Area mechanics are small enterprises with part time activity to inspect, maintain and repair handpumps. Even though the regular inspections would provide a basic work load, the economic base of such a job is not sufficient to support a mechanic full time. The suppliers would be advised to appoint small entrepreneurs who are already operating in a related field (car/motorcycle mechanics, 
household articles repairers) as their district representatives.

In order to perform the (preventive maintenance) inspections the area mechanic would need to be certified by GWSC. For this he would have to undergo the specified training. The training of area mechanics would be left to the supplier under the guidelines for pre-qualification.

\section{Spare parts distribution}

The pre-qualified suppliers will have to set up a network of spare parts outlets. The distribution network could have the following appearance:

- The national supplier keeps fully comprehensive stocks of spares in his central store.

- In each region the regional dealer will keep adequate stocks of spare parts. The financial risk will be with the national supplier. The regional dealer will pay a deposit of (let's say) $20 \%$ of the value of the spares that he has in stock. The margin for the regional dealer could be about $30 \%$ of the sales price. The quantity of spare parts in stock would have to be sufficient to cover at least $80 \%$ of all breakdowns. In the case that the components would not be in stock with the regional dealer, he should be able to order the parts within one week from the national supplier. The regional dealer would sell the spare parts either directly to communities or through the appointed area mechanic. The bulk of the spare parts sales would be parts that are to be replaced during the (preventive maintenance) inspection. This would allow the regional dealer to plan fairly closely the annual turnover on spares. These planning figures would help the national supplier to establish the demand for spare parts on national level.

- The area mechanic is the principal outlet for spare part sales. He makes the annual in-spections, replaces the fast wearing parts. He would have a margin of (let's say) $20 \%$ on all spares. He would stock only the parts he has to replace during the inspection. He would have to order from the regional dealer any other spare part required for repairs outside the scheduled maintenance. The distribution network would need to be set up in such a way that ( $95 \%$ of the) spare parts could be available at the area mechanic in less than a week.

GWSC would prepare a list of recommended spare parts sales prices for all the standardized pumps. This list would be reviewed and agreed on annually together with the prequalified suppliers/manufacturers. The price list would be published as recommended prices so that the communities would know how much the spare parts cost. 